\title{
Effect of exercise during rehabilitation on swimming performance, metabolism and function of muscle in rats
}

\author{
BY N. V. RAJU \\ National Institute of Nutrition, Indian Council of Medical Research, \\ Jamai-Osmania, Hyderabad-500007, India
}

(Received 8 October 1975 - Accepted 14 February 1977)

1. It has been observed previously that gastrocnemius muscles from rats rehabilitated after early nutritional stress have low endurance and oxidative capacity (Raju, 1974).

2. Exercise during rehabilitation reversed the effects of early malnutrition on muscle function and metabolism. The swimming performance of rehabilitated rats was poor and exercise during rehabilitation improved it.

3. The specific activity of gastrocnemius muscle myosin ATP phosphohydrolase (EC 3.6.1.3) was not altered by either early malnutrition or exercise.

The gastrocnemius muscles from rats rehabilitated after nutritional stress were observed to fatigue earlier than did those from control animals both in in vitro and in situ studies (Raju, 1974). Increased glycolytic activity and decreased oxidative capacity were also observed in these muscles. Endurance training is known to increase the in situ performance of the muscle (Barnard \& Peter, 1971) and its oxidative enzymes (Holloszy, 1967), and this adaptive response was observed even on low-protein diets (Fuge, Crews, Pattengale, Holloszy $\&$ Shank, 1968). The activity pattern of rats subjected to early malnutrition has been found to be altered (Frankova \& Barnes, 1968). It is possible that poor physical performance of rehabilitated rats reported earlier may be due to relative inactivity of these animals. It was of interest therefore to investigate whether forced physical activity during rehabilitation could reverse the impaired performance and enzyme 'make-up' of muscles of rats subjected to nutritional stress in early life.

The alterations in the enzyme profile may be due to alterations in the fibre composition (Raju, 1974). The specific activity of myosin ATP phosphohydrolase (EC 3.6.1.3) (MATPase) may indicate the proportion of slow and fast fibres in the muscle, as the specific activities of myosins from slow and fast muscles differ widely (Barany, Barany, Reckard \& Volpe, 1965; Siedel, 1967).

In this paper, studies on the swimming performance of rats subjected to early malnutrition and then rehabilitated on a normal diet with and without exercise are reported. Results of the in situ performance of muscles of these rats and the activities of representative glycolytic and oxidative enzymes and specific activity to M-ATPase are also presented.

\section{EXPERIMENTAL}

Pregnant female rats were maintained on stock colony diet. On the day of delivery, pups from all mothers were pooled and redistributed into two groups. One group of mothers nursed six pups each, while the other group of mothers nursed sixteen pups each (Kennedy, 1957). Dead pups, if any, during the first $3 \mathrm{~d}$ were replaced by pups nursed in a similar way. On 22nd day the pups were separated from the mother, and the male pups were maintained in individual cages. All female pups were rejected. Pups nursed in the litter of six/dam were 
Table 1. The experimental groups of rats and their dietary and exercise treatment

\begin{tabular}{lccc}
\multicolumn{1}{c}{ Group } & $\begin{array}{l}\text { No. of pups } \\
\text { with mother } \\
\text { before } \\
\text { weaning }\end{array}$ & $\overbrace{4-13 \text { weeks }}^{\text {old }}$ & $\begin{array}{c}\text { 13-26 weeks } \\
\text { old }\end{array}$ \\
Control & 6 & 200 & 200 \\
Control-exercised & 16 & 200 & 200 \\
Rehabilitated & 16 & 50 & 200 \\
Rehabilitated-exercised & 6 & 50 & 200 \\
Stock-colony rats & & 200 & -
\end{tabular}

Table 2. Composition of diets fed to rats

$\begin{array}{lcc}\text { Component }(\mathrm{g} / \mathrm{kg}) & \begin{array}{c}\text { Diet } 1 \\ (200 \mathrm{~g} \mathrm{pro}- \\ \text { tein } / \mathrm{kg})\end{array} & \begin{array}{c}\text { Diet } 2 \\ (50 \mathrm{~g} \mathrm{pro-} \\ \text { tein } / \mathrm{kg})\end{array} \\ \text { Groundnuts } & 149 & 38 \\ \text { Roasted Bengalgram flour } & 600 & 150 \\ \text { Wheat flour } & 200 & 50 \\ \text { Oil } & - & 45 \\ \text { Salt mixture* } & 40 & 40 \\ \text { Vitamin mixture } \dagger & 10 & 10 \\ \text { Choline chloride } & 1 & 1 \\ \text { Starch } & - & 666\end{array}$

* Wesson (1952) with zinc sulphate and cobalt chloride.

$\dagger$ National Academy of Sciences - National Research Council (1963).

given $200 \mathrm{~g}$ protein $/ \mathrm{kg}$ diet throughout the experimental period. Pups nursed in the litter of sixteen $/ \mathrm{dam}$ were given $50 \mathrm{~g}$ protein $/ \mathrm{kg}$ diet for 10 weeks. Thus the experimental rats were subjected to nutritional stress from birth to the age of 13 weeks. This corresponds to the period in which postnatal increase in muscle DNA is known to occur (Gordon, Kowalski \& Fritts, 1966).

They were then rehabilitated on a diet containing $200 \mathrm{~g}$ protein $/ \mathrm{kg}$. Just before rehabilitation the control and malnourished groups were divided randomly into two subgroups. One subgroup from each was exercised by forced swimming from the day of rehabilitation. For this purpose a water tank $0.61 \times 0.61 \times 0.61 \mathrm{~m}$ maintained at $30 \pm 1^{\circ}$ was used. Initially the swimming time was $10 \mathrm{~min} / \mathrm{d}$, which was gradually increased to $60 \mathrm{~min} / \mathrm{d}$, in two sessions of 30 min each. Details of groups and their treatment, and composition of the diets are presented in Tables 1 and 2 respectively.

\section{Swimming performance}

At the end of 13 weeks of rehabilitation, the 'swim-to-exhaustion' times of the rats (swim times) were determined after an overnight fast, with a weight equivalent to 100 or $70 \mathrm{~g} / \mathrm{kg}$ body-weight attached to the tail, $25 \mathrm{~mm}$ from the tip (Mcardle \& Montoye, 1966). The inability of the animal to surface for $10 \mathrm{~s}$ was taken as the point of exhaustion. The rats were rested for $5-7 \mathrm{~d}$ between two consecutive tests to avoid any training effect. Nonexercised rats were acclimatized to water by two periods of $10 \mathrm{~min}$ each. The swim time was also determined on a group of rats from the stock colony with body-weights similar to those of experimental rats. 


\section{In situ muscle performance}

For in situ studies, the gastrocnemius muscle complex with its circulation intact was isolated from rats anaesthetized with pentobarbital $(60 \mathrm{mg} / \mathrm{kg}$ body-weight). The muscle and the nerve were kept moistened with warm Ringer solution $\left(37^{\circ}\right)$. The muscle was stimulated through the sciatic nerve with a supramaximal current of $0.2 \mathrm{~m} / \mathrm{s}$ duration and frequency of 25 cycles/s and the performance was recorded by using an isotonic lever, attached to the distal tendon. The amplitude of contraction at $30 \mathrm{~min}$ expressed as $\%$ initial response', was used to evaluate the performance.

\section{Enzyme assays}

Immediately after the test, the rats were killed and the gastrocnemius muscles removed and extracted for myosin. The specific activity of calcium-stimulated M-ATPase purified by a series of three precipitations, was determined according to Siedel (1967).

The contralateral muscle was dissected and kept frozen at $-20^{\circ}$, and analysed within 1 week for fructosediphosphate aldolase (fructose-1,6-diphosphate D-glyceraldehyde-3phosphate-lyase; EC 4.1.2.13; FDA) activity according to the method of Taylor (1955), D-lactate: NAD oxidoreductase (EC 1.1.1.28; LDH) activity according to the method of Kornberg (1955) and L-malate:NAD oxidoreductase (decarboxylating) (EC 1.1.1.38; $\mathrm{MDH})$ activity according to the method of Ochoa (1955).

\section{Statistical analysis}

Statistical analysis of the results was carried out using a two-way analysis of variance test to bring out the effects of treatments and interaction. Individual groups are compared by Student's $t$ test.

The experiment was started with equal numbers of animals in all groups. But death of some rats during the study and loss of samples during processing resulted in the inconsistencies in the number of values for the various measurements. In the instance of the swim test, one rat from the control group was not tested as it had a short tail.

\section{RESULTS}

The results of analysis of variance are given in Table 3. Dietary treatment had a significant effect on body-weight $(P<0.001)$, swim times $(P<0.05)$, in situ performance $(P<0.001)$, muscle weight $(P<0.001)$, and on activities of FDA $(P<0.001), \mathrm{LDH}(P<0.05)$ and MDH $(P<0.001)$. Exercise had a significant effect on swim times $(P<0.05)$, in situ performance $(P<0.001)$ and $\mathrm{MDH}$ activity $(P<0.01)$ and a marginally-significant effect in the instance of LDH activity $(P<0 \cdot 1)$. Interaction was also significant in all instances mentioned where exercise had a significant effect, indicating the differential effect of exercise in the two dietary treatments.

\section{Growth}

Rehabilitated rats were found to be much smaller than the control rats. Exercise did not influence the body-weight gains of rats in either group (Table 6).

\section{Swim times}

The swim time of rats rehabilitated without exercise was similar to that of age-control rats but was significantly less than that of weight controls (Table 4).

Exercise significantly improved the swim time of rehabilitated rats but had no effect on the swim time of age-control rats. 


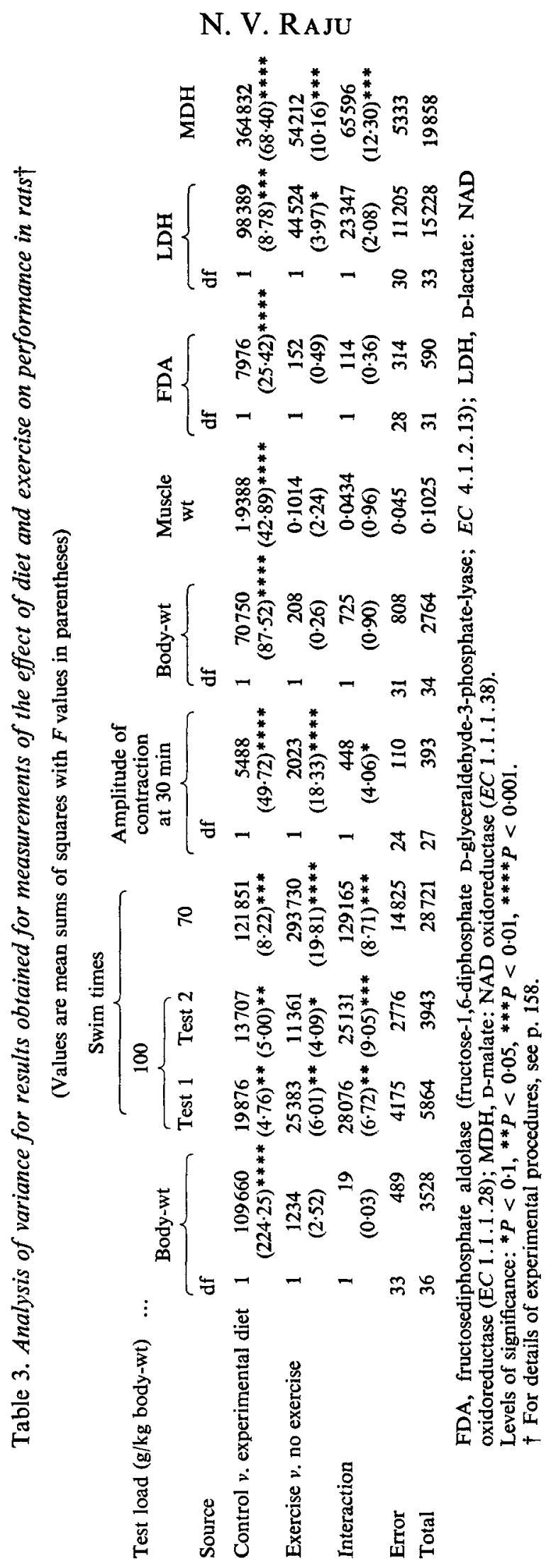


Table 4. 'Swim to exhaustion' time (swim time) $\dagger$ of chronically-undernourished and rehabilitated rats, well-nourished rats and stock-colony rats, and the effect of forced exercise on performance

(Mean values with their standard errors)

\begin{tabular}{|c|c|c|c|c|c|c|c|c|c|}
\hline \multirow[b]{4}{*}{ Group $\neq$} & \multirow{4}{*}{$\begin{array}{l}\text { No. of } \\
\text { rats }\end{array}$} & values & h thei & \multicolumn{6}{|c|}{ Swim time (s) } \\
\hline & & & & \multicolumn{6}{|c|}{ Test-load of $100 \mathrm{~g} / \mathrm{kg}$ body-wt $\S$} \\
\hline & & \multicolumn{2}{|c|}{ Body-wt (g) } & \multicolumn{2}{|c|}{ Test 1} & \multicolumn{2}{|c|}{ Test 2} & \multicolumn{2}{|c|}{$\begin{array}{c}\text { Test-load of } \\
70 \mathrm{~g} / \mathrm{kg} \text { body wt } \S\end{array}$} \\
\hline & & Mean & SE & Mean & SE & Mean & SE & Mean & SE \\
\hline $\begin{array}{l}\text { Control } \\
\text { Control-exercised } \\
\text { Rehabilitated } \\
\text { Rehabilitated-exercised } \\
\text { Stock-colony rats }\end{array}$ & $\begin{array}{r}9 \\
9 \\
10 \\
9 \\
8\end{array}$ & $\begin{array}{l}307 \\
308 \\
191 \\
207 \\
205\end{array}$ & $\begin{array}{r}10 \cdot 9 \\
5 \cdot 9 \\
5 \cdot 6 \\
5 \cdot 6 \\
4 \cdot 0\end{array}$ & $\begin{array}{l}126 \\
124 \\
121 \\
227^{*} \\
218^{*}\end{array}$ & $\begin{array}{r}4 \cdot 7 \\
10 \cdot 1 \\
17 \cdot 2 \\
37 \cdot 1 \\
28 \cdot 6\end{array}$ & $\begin{array}{l}126 \\
144 \\
133 \\
219^{*} \\
201^{*}\end{array}$ & $\begin{array}{r}5 \cdot 2 \\
15 \cdot 1 \\
14 \cdot 6 \\
27 \cdot 4 \\
19 \cdot 5\end{array}$ & $\begin{array}{l}308 \\
373 \\
317 \\
609 * * * \\
481 * *\end{array}$ & $\begin{array}{l}37 \cdot 5 \\
35 \cdot 6 \\
32 \cdot 4 \\
53 \cdot 0 \\
42 \cdot 3\end{array}$ \\
\hline
\end{tabular}

Value significantly different from that for 'rehabilitated' group: ${ }^{*} P<0.02,{ }^{* *} P<0.01,{ }^{* *} P<0.001$.

$\dagger$ For details of 'swim to exhaustion' test, see p. 158.

$\ddagger$ For details, see Table 1 .

$\S$ Weight to this amount attached to the tail.

Table 5. In situ performance of gastrocnemius muscle $\dagger$ of control rats and of chronicallyundernourished and rehabilitated rats, with and without forced exercise $\ddagger$

(Mean values with their standard errors for seven rats/group)

Amplitude of contraction at $30 \mathrm{~min}$ (\% of initial amplitude)

$\quad$ Group $\S$
Control
Control-exercised
Rehabilitated
Rehabilitated-exercised

$\begin{array}{ll}\text { Mean } & \text { SE } \\ 47 \cdot 0^{* * * * *} & 4 \cdot 3 \\ 56 \cdot 0^{* * * *} & 5 \cdot 2 \\ 11 \cdot 0 & 2 \cdot 3 \\ 36 \cdot 0^{* * * *} & 3 \cdot 5\end{array}$

Value significantly different from that for 'rehabilitated' group: $* * * * P<0.001$.

$\dagger$ For details of performance measurement, see p. 159.

$\ddagger$ For details of forced exercise schedule, see p. 158.

$\S$ For details, see Table 1.

The swim times of all rats were more than doubled when the weight attached was reduced from 100 to $70 \mathrm{~g} / \mathrm{kg}$ body-weight but differences between the groups were maintained.

\section{In situ muscle performance}

In in situ stimulation studies, muscles from rehabilitated rats maintained only $11 \%$ of their initial tension after $30 \mathrm{~min}$, while, in sharp contrast, muscles from control rats maintained $47 \%$ of their initial tension (Table 5). Exercise during rehabilitation resulted in a significant improvement in the tension maintained at $30 \mathrm{~min}(P<0.001)$, while there was only a small improvement in control rats. The interaction was significant $(P<0.001)$.

\section{Enzyme assays}

Values for glycolytic enzymes, FDA and LDH, were higher by $60 \%$ in muscles from rehabilitated rats (Table 6), as compared to those from control rats. Exercise during rehabilitation did not alter the FDA levels, but brought about a significant decrease in the 
Table 6. Activity of fructosediphosphate aldolase (fructose-1,6-diphosphate D-glyceraldehyde3-phosphate-lyase; EC 4.1.2.13; FDA) D-lactase: NAD oxidoreductase (EC 1.1.1.28; $L D H)$ L-maltate: $N A D$ oxidoreductase $(E C 1.1 .1 .38 ; M D H)$ in the muscle of control rats and of chronically-undernourished and rehabilitated rats with and without forced exercise $\dagger$

(Mean values with their standard errors; no. of rats in parentheses)

\begin{tabular}{|c|c|c|c|c|c|c|c|c|c|}
\hline \multicolumn{2}{|c|}{$\begin{array}{c}\text { Body-wt } \\
\text { (g) }\end{array}$} & \multicolumn{2}{|c|}{$\begin{array}{c}\text { Muscle wt } \\
\text { (g) }\end{array}$} & \multicolumn{2}{|c|}{$\begin{array}{c}\text { FAD } \\
\text { ( } \mu \mathrm{mol} \\
\text { inorganic } \\
\text { phosphate/g } \\
\text { wet } \\
\text { wt per min) }\end{array}$} & \multicolumn{2}{|c|}{$\begin{array}{c}\text { LDH } \\
(\mu \mathrm{mol} \\
\mathrm{NADH} / \mathrm{g} \\
\text { wet } \\
\text { wt per min) }\end{array}$} & \multicolumn{2}{|c|}{$\begin{array}{c}\text { MDH } \\
(\mu \mathrm{mol} \\
\text { NADH/g } \\
\text { wet } \\
\text { wt per min })\end{array}$} \\
\hline & SE & Mean & $\mathbf{S E}$ & Mean & $\mathbf{S E}$ & Mean & SE & Mean & SE \\
\hline $\begin{array}{l}* * * \\
(10)\end{array}$ & 9.9 & $\begin{array}{r}1 \cdot 83 * * * * \\
(10)\end{array}$ & 0.057 & $\begin{array}{r}57 \cdot 1 * * * * \\
(9)\end{array}$ & $5 \cdot 1$ & $\begin{array}{r}452^{* *} \\
(9)\end{array}$ & 36.6 & $\begin{array}{r}745^{* * * *} \\
(9)\end{array}$ & 24.9 \\
\hline $\begin{array}{l}* * * * \\
(8)\end{array}$ & $14 \cdot 0$ & $\begin{array}{r}1.91 * * * * \\
(8)\end{array}$ & 0.087 & $\begin{array}{r}56 \cdot 5 * * * \\
(7)\end{array}$ & $3 \cdot 3$ & $\begin{array}{r}432 * * * \\
(8)\end{array}$ & $22 \cdot 0$ & $\begin{array}{r}737 * * * * \\
(8)\end{array}$ & 35.8 \\
\hline (9) & $12 \cdot 0$ & $1 \cdot 32$ & 0.038 & $\begin{array}{r}92.0 \\
\text { (9) }\end{array}$ & 8.7 & 609 (9) & $46 \cdot 3$ & $\begin{array}{ll}455 & \\
& \text { (9) }\end{array}$ & $18 \cdot 3$ \\
\hline (8) & 3.4 & $\begin{array}{rr}1.46 \quad 0.12 & (8)\end{array}$ & & $\begin{array}{l}83 \cdot 8 \\
(7)\end{array}$ & $7 \cdot 3$ & $\begin{array}{r}484^{* *} \\
(8)\end{array}$ & 28.2 & $\begin{array}{r}623 * * * * \\
(8)\end{array}$ & $23 \cdot 2$ \\
\hline
\end{tabular}

Value significantly different from that for 'rehabilitated' group: ${ }^{* *} P<0.05 ;{ }^{* *} P<0.01,{ }^{* * * *} P<0.001$. $\dagger$ For details of forced-exercise schedule, see p. 159.

level of LDH. Exercise did not bring about any change in the levels of glycolytic enzymes of muscles from control rats.

MDH activity was low in the muscles of rehabilitated rats, compared to that of control rats. Exercise increased the activity of $\mathrm{MDH}$ in muscles of rehabilitated rats but not in those from control rats (Table 6). The interaction is significant $(P<0.001)$.

Neither early malnutrition nor exercise influenced the specific activity of Ca-stimulated M-ATPase. The specific activities of Ca-stimulated M-ATPase of the muscles of control rats, control-exercised rats, rehabilitated rats and rehabilitated-exercised rats were (mean $\pm \mathrm{SE}$; $\mu \mathrm{mol}$ inorganic phosphate/mg protein per min): $0.49 \pm 0.01,0.46 \pm 0.026,0.53 \pm 0.044$, $0.52 \pm 0.05$ respectively. These values were not significantly different from each other.

\section{DISCUSSION}

Endurance time is known to decrease with increasing work-load (Astrand \& Rodahl, 1970). Differences in endurance time may not be detected, even if they exist, if the workload is too high or too low. Hence swim times of rats were determined with different weights attached to the tail. Reduction of the weight from 100 to $70 \mathrm{~g} / \mathrm{kg}$ body-weight increased the swim times of all groups of rats but did not influence the differences between the groups. The swim times of controls and stock-colony rats with a weight of $70 \mathrm{~g} / \mathrm{kg}$ body-weight found here are comparable to those reported by Mcardle \& Monotoye (1966). In a few animals further reduction in the weight to $50 \mathrm{~g} / \mathrm{kg}$ body-weight increased the swim times to more than $15 \mathrm{~min}$.

The swim time of rats is known to be inversely related to body-weight (Mcardle \& Montoye, 1966). Hence the swim time of rehabilitated rats is not strictly comparable to that of control rats, as their body-weight was only $67 \%$ of that of control rats. The swim time of rehabilitated rats was only half that of stock-colony rats of similar body-weight. These 
results with the whole animal confirm and extend the earlier observations of decreased endurance of isolated muscles in rehabilitated rats.

Exercise nearly doubled the swim time of rehabilitated rats while it had no effect on the swim time of control rats. In normal rats training was shown to have no influence on the swim time of rats (Mcardle \& Montoye, 1966; Montoye, Nelson, Johnson \& Macnab, 1960). Hence the improvement in the swim time of rehabilitated rats by exercise is unlikely to be due to learning.

Earlier 'fatiguability' of the muscles of rats rehabilitated after malnutrition both in in vitro and in situ experiments has already been reported (Raju, 1974). Results presented here confirmed these earlier findings. The main object of the present study was to determine the adaptive response of these rats to endurance training or increased physical activity. Exercise had improved the in situ performance of muscles from rehabilitated rats, while no such effect was seen in control rats. These observations run parallel to the previous findings on the swimming performance.

Exercise during rehabilitation increased the activity of $\mathrm{MDH}$ and decreased the activity of $\mathrm{LDH}$, in the muscles, an effect similar to that observed by several workers in normal rats (Holloszy, Oscai, Don \& Mole, 1971; Baldwin, Winder, Terjung \& Holloszy, 1973; Dohm, Huston, Askew \& Fleshood, 1973).

In the present studies, exercise did not have any effect on the performance of control rats. While recent studies with rats (Holloszy, 1967) and other animals (Barnard, Edgerton \& Peter, 1970) trained by treadmill running have shown an adaptive increase in oxidative enzymes, in earlier investigations (Hearn \& Wainio, 1956; Gould \& Rawlinson, 1959) where swimming was used as a method of physical activity, alterations were not seen. This has been attributed to relatively mild work-load imposed by swimming (Holloszy, 1967). It is significant in this context that swimming did produce good response in the rehabilitated rats.

Several recent studies (Pette, Staudte \& Vrbova, 1972; Pette, Smith, Staudte \& Vrbova, 1973; Riley \& Allin, 1973), have indicated that the nature of stimulus to the muscle (phasic or tonic) influences its metabolic profile and therefore its function. Reduced duration of activity and increased intensity of action, which have been observed in rehabilitated rats (Frankova \& Barnes, 1968; Barnes, 1971) are probably responsible for the metabolic changes in the muscle of rehabilitated rats and their response to mild work-load training.

On the basis of their different morphological, biochemical and physiological characteristics, three distinct types of fibre (fast high oxidative, fast low oxidative and slow oxidative) have been identified in mammalian skeletal muscles (Barnard, Edgerton, Furukawa \& Peter, 1971). The alterations in fibre composition in response to exercise has been a subject of several recent studies (Barnard et al. 1970; Faulkner, Maxwell, Brook \& Lieberman, 1971; Baldwin, Klinkerfuss, Terjung, Mole \& Holloszy, 1972). The specific activity of M-ATPase of the muscle has been shown to be inversely related to its contraction time (Barany, 1967). Further, changes in contraction time during development and in crossinnervation studies were observed to be associated with parallel changes in the specific activity of M-ATPase (Close, 1972). Hence the specific activity of M-ATPase may serve as a biochemical indicator for the fast and slow fibre 'makeup' of the muscle. The postnatal increase in the specific activity of M-ATPase (Trayer \& Perry, 1966) was found to be influenced by the activity pattern of the animal (Perry, 1973). Undernutrition may also be expected to influence the specific activity of M-ATPase directly, as well as by modifying the activity pattern of the animal. However, results presented here show that the specific activity of Ca-stimulated M-ATPase of gastrocnemius muscles was not altered either by early malnutrition or by exercise. The explanation for exercise not influencing the M-ATPase activity in the present study may be because the animals were grown-up. Other workers have 
also observed that exercise in adult animals does not alter the specific activity of M-ATPase (Barnard et al. 1971; Syrovy, Gutman \& Melichna, 1972). These results suggest that there is probably no change in the proportion of fast and slow fibres in the rehabilitated rat muscles.

Endurance of the muscle is known to be related to its oxidative capacity, which changes in response to the activity of the animal probably by alterations in the oxidative enzymes of all types of fibres (Baldwin et al. 1972) or by an interconversion of fast low oxidative and fast high oxidative fibres (Barnard et al. 1970). In the present studies also, changes in the performance of the animal are associated with changes in the activity of oxidative enzyme $\mathrm{MDH}$ of the muscle, probably resulting from similar changes.

The main finding of practical importance of this study is that forced physical activity during rehabilitation was associated with a significant improvement in the swimming performance of the animal and in situ performance of the gastrocnemius muscle. In these studies rats were subjected to chronic, moderate undernutrition. Whether such a response occurs in rats subjected to severe undernutrition as well needs to be investigated, that this may be so is suggested by the studies of Torun, Schutz, Bradfield \& Viteri (1975) who have observed that physical activity stimulated a greater improvement in basal metabolic rate and growth-in-height of children recovering from protein-energy malnutrition.

The author is grateful to Dr S. G. Srikantia (Director) and Dr B. S. Narasinga Rao (Deputy Director), National Institute of Nutrition, Jamai-Osmania, Hyderabad-500007, for their helpful suggestions during the study and preparation of the manuscript. The author is grateful to Mr A. Nadamuni Naidu for his help in statistical analysis. The author acknowledges the technical help of D. Laxminarayana.

\section{REFERENCES}

Astrand, P. O. \& Rodahl, K. (1970). Textbook of Work Physiology, p. 292, New York: Mcgraw-Hill. Baldwin, K. M., Klinkerfuss, G. H., Terjung, R. L., Mole, P. A. \& Holloszy, J. O. (1972). Am. J. Physiol. 222, 373.

Baldwin, K. M., Winder, W. W., Terjung, R. L. \& Holloszy, J. O. (1973). Am. J. Physiol. $225,962$.

Barany, M. (1967). J. gen. Physiol. 50, 197.

Barany, M., Barany, K., Reckard, T. \& Volpe, A. (1965). Archs Biochem. Biophys. 109, 185.

Barnard, R. J., Edgerton, V. R. \& Peter, J. B. (1970). J. appl. Physiol. 28, 762.

Barnard, R. J., Edgerton, V. R., Furukawa, T. \& Peter, J. B. (1971). Am. J. Physiol. 220, 410.

Barnard, R. J. \& Peter, J. B. (1971). J. appl. Physiol. 31, 904.

Barnes, R. H. (1971). Fedn Proc. Fedn Am. Socs exp. Biol. 30, 1429.

Close, R. (1972). Physiol. Rev. 52, 129.

Dohm, G. L., Huston, R. L., Askew, W. E. S., Fleshood, L. H. (1973). Can. J. Biochem. 51, 849.

Faulkner, J. A., Maxwell, L. C., Brook, D. A. \& Lieberman, D. H. (1971). Am. J. Physiol. $221,291$.

Frankova, S. \& Barnes, R. H. (1968). J. Nutr. 96, 477.

Fuge, K. W., Crews, E. L., Pattengale, P. K., Holloszy, J. O. \& Shank, R. E. (1968). Am. J. Physiol. 215 660.

Gordon, E. E., Kowalski, K. \& Fritts, M. (1966). Am. J. Physiol. 210, 1033.

Gould, M. K. \& Rawlinson, W. A. (1959). Biochem. J. 73, 41.

Hearn, G. R. \& Wainio, W. W. (1956). Am. J. Physiol. 185, 348.

Holloszy, J. O. (1967). J. biol. Chem. 242, 2278.

Holloszy, J. O., Oscai, L. B., Don, T. J. \& Mole, P. A. (1971). Biochem. Biophys. Res. Commun. 40, 1368.

Kennedy, G. C. (1957). J. Endocrinol. 15, 9.

Kornberg, A. (1955). Meth. Enzym. 1, 441.

Mcardle, W. D. \& Montoye, H. J. (1966). J. appl. Physiol. 21, 1431.

Montoye, H. J., Nelson, R., Johnson, P. \& Macnab, R. (1960). Res. Am. Ass. Hith phys. Educ. $31,474$.

National Academy of Sciences - National Research Council (1963). Evaluation of Protein Quality, publ. no. 1100. Washington, DC: National Academy of Sciences.

Ochoa, S. (1955). Meth. Enzym. 1, 735.

Perry, S. V. (1973). In The physiology and Biochemistry of Muscle as a Food, vol. 2, p. 537 [E. J. Briskley, R. G. Gassens and B. R. Marsch, editors]. Wisconsin: University of Wisconsin Press. 
Pette, D., Smith, M. E., Staudte, H. W. \& Vrbova, G. (1973). Pflugers Arch. ges. Physiol. $338,287$.

Pette, D., Staudte, H. W. \& Vrbova, G. (1972). Naturwissenschaften 59, 469.

Raju, N. V. (1974). Life Sci. 15, 949.

Riley, D. A. \& Allin, E. F. (1973). Expl Neurol. 40, 391.

Siedel, J. C. (1967). J. biol. Chem. 242, 5623.

Syrovy, I., Gutman, E. \& Melichna, J. (1972). Physiologia Bohemosloy, 21, 638.

Taylor, J. F. (1955). Meth. Enzym. 1, 310.

Torun, B., Schutz, Y., Bradfield, R. \& Viteri, F. E. (1975). In Abstracts of Xth International Congress of Nutrition, abstr. no. 314, p. 29 [H. Koishi, N. Hosoya and K. Yasumoto, editors]. Kyoto: Science Council of Japan.

Trayer, J. P. \& Perry, S. V. (1966). Biochem. Z. 345, 57.

Wesson, L. G. (1952). Science, N.Y. 75, 339. 